\title{
Kronik Stresin Adrenal Bez Üzerine Etkilerinin Morfometrik ve Histokimyasal Yöntemlerle Sıçan Modeli Üzerinde Araştırılması
}

\section{An Investigation of Effects of Chronic Stress on Adrenal Gland by Using Morphometric and Histochemical Methods on Rats Model}

\author{
Semin Gedikli ${ }^{1 *}$, Elvan Şahin ${ }^{2}$ \\ ${ }^{1}$ Atatürk Üniversitesi, Veteriner Fakültesi, Histoloji ve Embriyoloji Anabilim Dalı, Erzurum, Türkiye.
}

${ }^{2}$ Sakarya Üniversitesi, Tıp Fakültesi, Histoloji ve Embriyoloji Anabilim Dalı, Sakarya, Türkiye.

e-mail: semingedikli@gmail.com, elvansahin@ sakarya.edu.tr

ORCID: 0000-0001-8238-7226

ORCID: 0000-0001-8585-9903

*Sorumlu yazar/ Corresponding Author: Semin Gedikli

Gönderim Tarihi / Received: 24.07.2020

Kabul Tarihi / Accepted: 03.11.2020

DOI: $10.34087 /$ cbusbed. 773244

Öz

Giriş ve Amaç: Vücuda çeşitli hasarlar veren stres faktörlerine karşı organizmada yanıt oluşturan yapıların başında nöroendokrin sistemin geldiği bilinmektedir. Biz de sıçanlarda kronik stres modeliyle adrenal bezlerde oluşabilecek morfolojik ve histolojik değişiklikleri araştırmayı amaçladık.

Gereç ve Yöntemler: 24 Sprague Dawley sıçan, her birinde 6'şar erkek veya dişi sıçan olan 4 gruba ayrıldı. 14 gün, dişi ve erkek kontrol gruplarına hiçbir uygulama yapılmazken, stres gruplarına kronik stres prosedürü uygulandı. Sıçanların ağırlıkları $3 \mathrm{kez}$ tartıldı. Fiksasyondan sonra rutin histolojik işlemlerden geçirilen adrenal bezler parafine gömüldü. Alınan kesitler Hematoksilen-Eozin, PAS ve Masson Trikrom yöntemleriyle boyanarak histopatolojik açıdan incelendi. Mikrometrik okülerle kesitlerin morfometrik değerlendirmesi yapılarak tüm ölçüm sonuçlarının istatistiksel analizleri gerçekleştirildi.

Bulgular: Dişi stres grubunun ağırlığı kontrole kıyasla anlamlı derecede azalırken, erkek stres grubundaki ağırlık artışı kontrol grubuna kıyasla anlamlı bulunmadı. Ayrıca hem dişi hem de erkek stres gruplarının korteks kalınlığında, kendi kontrollerine kıyasla anlamlı bir artış mevcuttu. Stres gruplarının adrenal bezlerinde nükleer ve sitoplazmik dejenerasyonlar, adrenokortikal hiperplazi, makrofajlar, sinüzoidlerde dilatasyon ve bağ dokusunda artış gözlendi.

Sonuç: Kronik stres dişilerde kilo kaybına, erkek ve dişilerde kortekste kalınlaşmaya ve hücresel dejenerasyonlara sebep olabilmektedir.

Anahtar kelimeler: Adrenal bez, Adrenal hiperplazi, Kronik stres, Morfometri, Siçan.

\section{Abstract}

Objective It's known that neuroendocrine system are leading structures that respond to stress factors that cause various damages to the body. We aimed to investigate the morphological and histological changes that may occur in the rats' adrenal glands with the model of chronic stress.

Material and Methods: 24 Sprague Dawley rats were divided into 4 groups, 6 male or female rats each. In 14 days, no treatment was applied to the female and male control groups, while stress groups were subjected to chronic stress procedure. Weights of rats were weighed 3 times. After fixation, the adrenal glands undergoing routine histological procedures were embedded in paraffin. The sections were stained with Hematoxylin-Eosin, PAS and Masson Trichrome methods and examined histopathologically. Morphometric evaluation of sections with micrometric ocular, statistical analysis of all measurement results were performed.

Results: While the weight of the female stress group decreased significantly compared to the control, the increase in weight in the male stress group was'nt significant compared to the control group. In addition, there was a significant increase in cortex thickness in both the female and male stress groups compared to their own controls. Nuclear and cytoplasmic degenerations, adrenocortical hyperplasia, macrophages, sinusoidal dilatation and connective tissue increase were observed in the stress groups' adrenal glands. 
Conclusion: Chronic stress can cause weight loss in females, thickening in the cortex of males and females, and cellular degenerations..

Keywords: Adrenal gland, Adrenal hyperplasia, Chronic stress, Rat, Morphometry.

\begin{abstract}
1. Giriş
Çeşitli etkenler sebebiyle vücut çalışmasında dengesizliğe, sinir sisteminde bozukluğa ve psişik gerilime neden olan stres [1], yaşamın her alanında karşılaşılabilen, bireylerin bir engel ya da tehditle karşılaşması durumunda göstermiş oldukları tepki [2] veya fiziksel, psikolojik ve davranışsal değişimlere yol açan çevresel veya içsel şartlara karşı bir uyum süreci olarak tanımlanmaktadır [3]. Bireyde strese neden olan durumlar genellikle, birey tarafindan kontrol edilemeyen, istem dışı gelişen ve kişinin dayanabileceğinden fazla iş yükü ile yüklendiği durumlardır [4]. Stres faktörleri oldukça geniş kapsamlıdır; anksiyete, travma, malnütrisyon, yaşlılık, soğuk, sıcak, X ışınları, obezite, cerrahi ve medikal tedavi, enfeksiyonlar, azalmış müsküler egzersizler, depresyon ve bağımlılıklar stres faktörlerinin ancak birkaç tanesini oluşturmaktadır [1].
\end{abstract}

Stres faktörleri, uzun süreli olursa veya tekrarlama eğilimi gösterirse stres kronik bir hal alır ve vücutta var olan homeostazisin bozulmasina neden olur. Kronik stres geliştiği zaman dokularda reaktif oksijen türleri (ROS) artarak organizmada oksidatif stresin gelişmesine yol açmaktadır [5]. Eğer stres kronik bir hal alır ve organizmadaki adaptasyon mekanizmaları çalışmazsa, hormonal dengede uzun vadede düzensizlikler meydana gelmekte ve endokrin sistem kronik stresten etkilenmektedir. Buna bağlı olarak da birçok psikiyatrik ve fiziksel hastalığın alt yapısı şekillenmeye başlamaktadır [6, 7].

Vücutta kronik strese ilk yanıt, merkezi sinir sistemi ve endokrin sistem tarafından başlatılmaktadır [8]. Stres faktörüne karşı uygun fizyolojik yanıtı oluşturabilmek organizmanın hayatta kalabilmesi için en önemli şarttır [9]. Fizyolojik yanıt, nöroendokrin sistem elemanlarından olan hipotalamus-hipofiz-adrenal (HPA) aksının ve sempatik sinir sisteminin aktivasyonu ile oluşturulmaktadır [10, 11]. Adrenal bezler de bu sistemlerin vazgeçilmez bir parçası olarak stres faktörlerinden en çok etkilenen organların başında gelmektedir [9, 12].

Kronik beklenmedik stres (chronic mild stres-CMS) modeli, bazı kisitlamalar uygulamak suretiyle hayvanlarda meydana gelebilecek sinirsel ve hormonal düzeydeki bir takım değişiklikleri kısa sürede ortaya çıkararak vücudun incelenebilmesine firsat veren ve depresyon modeli oluşturmak için sıkça kullanılan, oldukça kabul gören bir modeldir [13]. Biz de vücuttaki nöroendokrin sistem içinde önemli yeri olan adrenal bezlerde strese bağlı olarak ortaya çıkabilecek birtakım değişiklikleri, sıçan modeli üzerinde çeşitli morfometrik ve histokimyasal yöntemler kullanarak araştırmayı amaçladik.

\section{Materyal ve Metot \\ 2.1 Etik kurul kararl ve deneklerin temini}

\section{Çalışmamız, Atatürk Üniversitesi Rektörlüğü Hayvan}

Deneyleri Yerel Etik Kurulu Başkanlığının 24.04.2009 tarih ve 5 sayılı oturumunda 42 no'lu kararı ile etik kurallara uygun olarak kabul görmüştür. Çalışmanın deneysel aşamaları Tıbbi Deneysel Uygulama ve Araştırma Merkezi'nde ve Atatürk Üniversitesi Tip Fakültesi Histoloji ve Embriyoloji Anabilim Dalı Laboratuarlarında gerçekleştirilmiștir. Deneyde kullanılan sıçanlar, Atatürk Üniversitesi Tıbbi Deneysel Uygulama ve Araştırma Merkezinden temin edilmiştir.

\subsection{Deney gruplarl}

Deneyde ortalama 250-300 gr ağırlığında, 12'si dişi, 12'si erkek olmak üzere toplam 24 adet Sprague Dawley cinsi sıçan kullanıldı. Tüm sıçanlar 12 saat aydınlık, 12 saat karanlık ortamda ve oda sicaklığında $\left(22-24^{0} \mathrm{C}\right)$ tutuldular. Ticari yem ile beslendiler, deney süresince musluk suyunu ve yemi serbest olarak tükettiler. Erkek ve dişi sıçanlar birbirinden ayrıldıktan sonra kendi aralarında rastgele ve eşit sayıda olacak şekilde tekrar ikişer gruba ayrıldılar. Böylece her birinde 6'şar erkek ve 6'şar dişi sıçan olan 4 kafes oluşturuldu ve gruplarımız:

Grup 1 (Dişi Kontrol Grubu): Deney boyunca standart yem ve musluk suyuyla beslenen, stres uygulanmayan dişi grubu,

Grup 2 (Dişi Stres Grubu): Deney boyunca standart yem ve musluk suyuyla beslenen, kronik stres prosedürü uygulanan dişi grubu,

Grup 3 (Erkek Kontrol Grubu): Deney boyunca standart yem ve musluk suyuyla beslenen, stres uygulanmayan erkek grubu,

Grup 4 (Erkek Stres Grubu): Deney boyunca standart yem ve musluk suyuyla beslenen, kronik stres prosedürü uygulanan erkek grubu, olarak belirlendi.

\subsection{Deneysel uygulama}

Çalışmamızda uygulamak istediğimiz "kronik beklenmedik stres" modeli ile ilgili yaptı̆̆ımız literatür araştırmasında hem deneyin süresi hem de deneklere uygulanan işlemler açısından birçok prosedür olduğunu gördük [9, 13-15]. Biz de bu literatürler 1şığında Tablo 1 'de belirtilen "Kronik Beklenmedik Stres" prosedürünü düzenleyerek 14 gün boyunca, Grup 2 ve Grup 4'e uyguladık.

Grup 1 ve Grup 3'teki sıçanlara ise çalışmanın başından itibaren hiçbir uygulama yapılmadı. Sıçanların vücut ağırlıkları deneye başlamadan önce, birinci haftanın sonunda ve deney sonunda olmak üzere toplam $3 \mathrm{kez}$ tartılarak kaydedildi. Bütün sıçanlar kendi gruplarının uygulaması bittiğinde eter anestezisi altında feda edilerek adrenal bezleri çıkarıldı.

\subsection{Histokimyasal prosedür}

Deneyin ardından feda edilen sıçanlardan alınan adrenal bezler, hacimleri ölçüldükten sonra \%10'luk formaldehit solüsyonuna konuldu. Alınan doku örnekleri alkol ve ksilol serilerinden geçirilerek parafine gömüldü [16]. 
Tablo 1: Kronik stres modeli oluşturmak için 14 gün süreyle uygulanan deneysel prosedür.

\begin{tabular}{|c|c|}
\hline GÜN & UYGULANAN İŞLEM \\
\hline 1. gün & $\begin{array}{l}60 \text { dakika süreyle, } 6 \text { sıçan bir arada } \\
30 \mathrm{~cm} \times 30 \mathrm{~cm} \times 30 \mathrm{~cm} \text { boyutlarındaki tahta } \\
\text { kutuda tutuldu, daha sonra çıarılarak } \\
\text { kafeslerine konuldu. }\end{array}$ \\
\hline 2. gün & $\begin{array}{l}6 \text { siçan } 18^{\circ} \mathrm{C} \text { sicaklıktaki su havuzunda } 10 \\
\text { dakika yüzdürüldü. }\end{array}$ \\
\hline 3. gün & $\begin{array}{l}\text { Siçanlara } 1,0 \text { miliamperlik elektrik şoku } 10 \\
\text { sn uygulanıp akım kesildi, } 120 \text { sn } \\
\text { beklendikten sonra ayn işlem } 10 \text { dakika } \\
\text { boyunca (toplam } 5 \mathrm{kez} \text { ) tekrarlandı. }\end{array}$ \\
\hline 4. gün & $\begin{array}{l}\text { Sıçanlar kendi kafeslerinden çıkarılarak, } \\
\text { ayrı ayrı kafeslere konuldular, } 12 \text { saat } \\
\text { süreyle tek bırakıldılar. On ikinci saatin } \\
\text { sonunda kendi kafeslerine alındılar. }\end{array}$ \\
\hline 5. gün & $\begin{array}{l}6 \text { siçan, } 45^{0} \text { lik eğimle duran } \\
30 \mathrm{~cm} 30 \mathrm{~cm} \times 30 \mathrm{~cm} \text { boyutlarındaki tahta } \\
\text { kutu içinde } 1 \text { saat boyunca bir arada } \\
\text { tutuldular. Süre bitiminde kendi kafeslerine } \\
\text { konuldular. }\end{array}$ \\
\hline 6. gün & $\begin{array}{l}6 \text { sıçan } 30 \mathrm{~cm} \times 30 \mathrm{~cm} \times 30 \mathrm{~cm} \text { boyutlarındaki } \\
\text { tahta kutuya konularak } 30 \text { dakika boyunca } \\
\text { sallandılar ve aynı anda } 240 \mathrm{hz} \text { 'lik gürülttüye } \\
\text { maruz bırakıldılar. }\end{array}$ \\
\hline 7. gün & $\begin{array}{l}250 \mathrm{ml} \text { su ile sslatılmış talaş zemin üzerinde } \\
6 \text { sıçan } 2 \text { saat süreyle bir arada tutuldu. }\end{array}$ \\
\hline 8. gün & $\begin{array}{l}6 \text { sıçan, } 31^{\circ} \mathrm{C} \text { sıcaklıktaki su havuzunda } 10 \\
\text { dakika yüzdürüldü. }\end{array}$ \\
\hline 9. gün & $\begin{array}{l}\text { Siçanlara } 1,5 \text { miliamperlik elektrik şoku } 15 \\
\text { sn uygulanıp akım kesildi, } 150 \text { sn } \\
\text { beklendikten sonra ayn işlem } 10 \text { dakika } \\
\text { boyunca (toplam } 4 \mathrm{kez} \text { ) tekrarlandı. }\end{array}$ \\
\hline 10. gün & $\begin{array}{l}250 \mathrm{ml} \text { su ile 1slatılmış talaş zemin üzerinde } \\
6 \text { sıçan } 3 \text { saat süreyle bir arada tutuldu. }\end{array}$ \\
\hline 11. gün & $\begin{array}{l}\text { Siçanlar kendi kafeslerinden çıkarılarak, } \\
\text { ayrı ayrı kafeslere konuldu ve } 24 \text { saat } \\
\text { süreyle tek bırakıldılar. }\end{array}$ \\
\hline 12. gün & $\begin{array}{l}6 \text { siçan, } 45^{0} \text { 'lik eğimle duran } \\
30 \mathrm{~cm} 30 \mathrm{~cm} \times 30 \mathrm{~cm} \text { boyutlarındaki tahta } \\
\text { kutu içerisinde } 2 \text { saat boyunca bir arada } \\
\text { tutuldu. }\end{array}$ \\
\hline 13. gün & $\begin{array}{l}250 \mathrm{ml} \text { su ile 1slatılmış talaş zemin üzerinde } \\
6 \text { sıçan } 4 \text { saat süreyle bir arada tutuldu. }\end{array}$ \\
\hline 14. gün & $\begin{array}{l}6 \text { sıçan } 30 \mathrm{~cm} \times 30 \mathrm{~cm} \times 30 \mathrm{~cm} \text { boyutlarındaki } \\
\text { tahta kutuya konularak } 45 \text { dakika boyunca } \\
\text { sallandı ve aynı anda da } 240 \text { hz'lik } \\
\text { gürültüye maruz bırakıldı. }\end{array}$ \\
\hline
\end{tabular}

Parafin bloklardan Leica RM2125RT (Leica, Tokyo, Japan) marka mikrotom yardımı ile 5-7 $\mu$ m kalınlığında kesitler alındı. Alınan kesitler, genel histolojik yapılarını değerlendirilebilmek için Hematoksilen-Eozin, bağ dokusu değişikliklerini inceleyebilmek için Masson Trikrom, retiküler lif ve glikoprotein içeriğini gözlemleyebilmek için de Periyodik Asit Schiff (PAS) yöntemiyle boyandılar. Kesitler histopatolojik hasarlar yönünden Nikon DS-Fi1 (Nikon, Tokyo, Japan) marka bir kamera monte edilmiş Nikon Eclipse E600 (Nikon,
Tokyo, Japan) marka 1şı mikroskobunda incelendi ve fotoğrafları çekildi

\subsection{Histokimyasal prosedür}

Doku örnekleri alkol ve ksilol serilerinden geçirilerek parafine gömüldü [16]. Parafin bloklardan Leica RM2125RT (Leica, Tokyo, Japan) marka mikrotom yardımı ile 5-7 $\mu \mathrm{m}$ kalınlığında kesitler alındı. Alınan kesitler, genel histolojik yapılarını değerlendirilebilmek için Hematoksilen-Eozin, bağ dokusu değişikliklerini inceleyebilmek için Masson Trikrom, retiküler lif ve glikoprotein içeriğini gözlemleyebilmek için de Periyodik Asit Schiff (PAS) yöntemiyle boyandılar. Kesitler histopatolojik hasarlar yönünden Nikon DS-Fi1 (Nikon, Tokyo, Japan) marka bir kamera monte edilmiş Nikon Eclipse E600 (Nikon, Tokyo, Japan) marka 1şık mikroskobunda incelendi ve fotoğrafları çekildi

2.6 Işı mikroskobik kesitlerin morfometrik değgerlendirmesi

Boyanmış kesitlerde mikrometrik ölçüm yapabilmek için, öncelikle mikroskopta kalibrasyon işlemi gerçekleştirildi. $\mathrm{Bu}$ amaçla mikroskoba uyarlanan mikrometrik oküler ve objektif yardımıyla mikrometrik lam üzerinde ölçek ayarlaması yapıldı. Daha sonra, deney gruplarımıza ait doku kesitlerinin bulunduğu lamlarda mikrometrik düzeyde ölçümlere geçildi. Kontrol (Grup 1, Grup 3) ve stres gruplarına (Grup 2, Grup 4) ait sıçanlardan alınan adrenal bezlerin total korteks kalınlıkları mikrometrik objektif kullanılarak ölçüldü.

\section{7 İstatistiksel analizler}

Çalışmada dört gruptan elde edilen vücut ağırlıkları, organ hacimleri ve mikrometrik ölçüm değerleri ile ilgili verilerin istatistiksel analizleri için farklı testler kullanıldı. Bu amaçla, Microsoft SPSS 17.0 sürümü kullanılarak; vücut ağırlıklarını ve organ hacimlerini değerlendirmek için Post Hoc Tests, total korteks kalınlıklarını kıyaslamak için de One Way ANOVA testi uyguland1.

\section{Bulgular ve Tartışma}

3.1. Bulgular

3.1.1. Vücut ăğtlıklart ile ilgili bulgular

Çalışmadaki bütün sıçanların deneyin başında, ortasında ve 14. günün sonunda ölçülen vücut ağırlık değerleri aşağıdaki grafikte özetlenmiştir (Şekil 1).

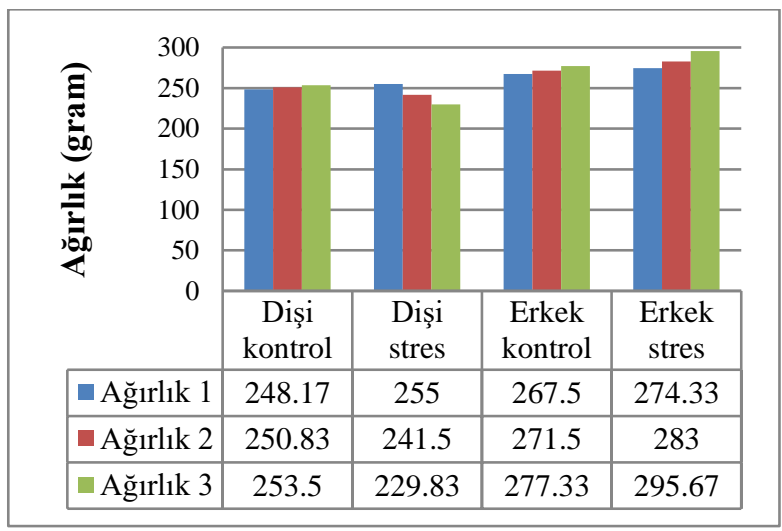

Şekil 1. Grupların vücut ağırlık ortalamalarını gösteren grafik. 
Sıçanların vücut ağırlıkları bakımından, birinci tartım sonuçlarına göre kontrol ve stres grupları arasında istatistiksel olarak anlamlı bir fark bulunmad $1(\mathrm{p}>0,05)$. İkinci tartım sonuçlarına göre, her iki cinsiyetin kontrol ve stres grupları arasında vücut ağırlıkları bakımından anlamlı bir fark görülmezken ( $\mathrm{p}>0,05)$, dişi stres ve erkek stres grupları arasında önemli bir fark bulundu $(\mathrm{p}<0,05)$. Yani, ağırlık kaybettiği görülen dişi stres grubu ile ağırlıklarında artış olan erkek stres grubu arasındaki fark istatistiksel olarak anlamlıydı. Üçüncü tartım sonuçlarına göre, dişi stres grubundaki sıçanların kontrole kıyasla önemli derecede ağırlık kaybettikleri gözlendi $(p<0,05)$. Erkek stres grubundaki sıçanların ağırlığı artmış olmasına rağmen bu artış, kontrolle kıyaslandığında istatistiksel olarak anlamlı bulunmadı ( $\mathrm{p}>0,05)$. Dişi stres grubu ile erkek stres grubu arasında ise istatistiksel olarak önemli bir fark olduğu görüldü ( $\mathrm{p}<0,05)$.

\subsubsection{Total korteks kalınlıklarlyla ilgili bulgular}

Diși stres grubunda, sağ ve sol adrenal bezlerin ortalama total korteks kalınlığının, dişi kontrol grubundan anlamlı derecede fazla olduğu görüldü $(\mathrm{p}<0,05)$. Erkek stres grubunda da, sağ ve sol adrenal bezlerin ortalama total korteks kalınlığ derecede artmıştı $(\mathrm{p}<0,05)$.

Strese maruz birakılan hem dişi hem de erkek sıçanlardaki adrenal korteks kalınlığı, kendi kontrol gruplarındakine kıyasla artmıştı; bunun yanı sıra erkek stres grubundaki korteks kalınlığ kıyaslandığında da istatistiksel olarak anlamlı derecede $(\mathrm{p}<0,05)$ daha fazlaydı (Şekil 2).

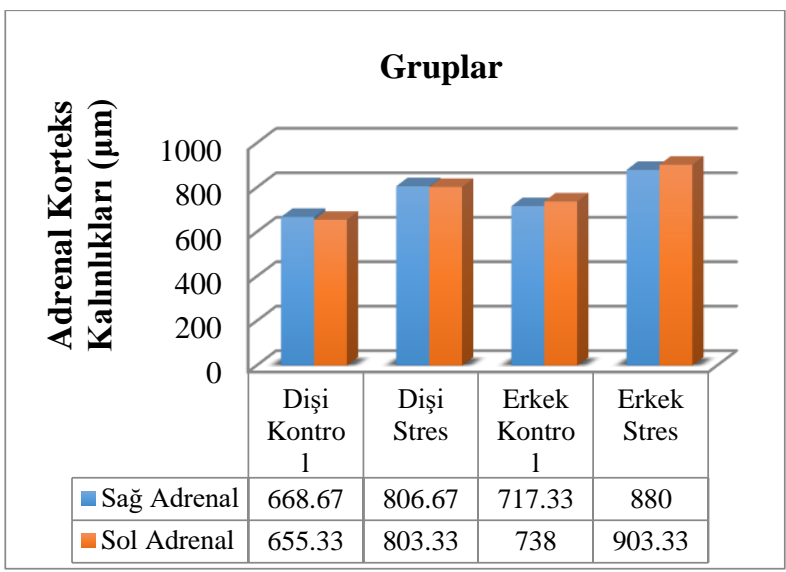

Sekil 2. Tüm gruplarda sağ ve sol adrenal beze ait korteks kalınlıkların gösteren grafik.

\subsubsection{Hematoksilen-Eozin boyama ile elde edilen bulgular}

Dişi kontrol (Şekil 3) ve erkek kontrol (Şekil 4) grubuna ait adrenal bez kesitleri incelendiğinde bezin parankimadan zengin, bağ dokusu açısından fakir bir organ olduğu ve düzensiz sıkı bağ dokusundan oluşan bir kapsül tarafından çevrelendiği gözlendi. Kapsülün altından başlayan parankima dişta korteks ve içte medulladan oluşmaktaydı. Korteks dıştan içe doğru zona glomeruloza, zona fasikülata ve zona retikülaris adı verilen üç tabakadan oluşmaktaydı. Zona glomeruloza, sıkıca paketlenmiş globüler hücre kümeleri şeklinde düzenlenmişti. Hücrelerin aralarında ince bağ dokusu lifleri ve yer yer kapillerler izlenmekteydi. Zona fasikülata, uzun ışınsal kordonlar şeklinde düzenlenmiş, soluk boyanan büyük polihedral şekilli hücrelerden oluşmaktaydı. Hücre kordonlarının arasında sinüzoidal kapillerler dikkati çekmekteydi. Bu tabakanın özellikle zona glomerulozaya yakın dış kısmındaki hücreleri, intrasitoplazmik iri vakuoller şeklinde görülen lipid damlalarına sahipti. Zona retikülaris hücreleri ise sinüzoidal kapillerlerle birbirinden ayrılmış düzensiz biçimde anastomozlaşan kordonlar şeklindeydi. Medulla, kortekse kıyasla daha soluk boyanan ökromatik büyük nukleusları olan hücrelerden oluşmaktaydı. Yuvarlak kümeler veya kısa kordonlar şeklinde düzenlenmiş olan medulla hücreleri arasında ince bağ dokusu septumları, sinüzoidal tipte kapillerler, kalın duvarlı damarlar ve yer yer korteksten aşağıya sarkmış koyu eozinofil sitoplazmalı zona retikülaris hücreleri yer almaktaydı.

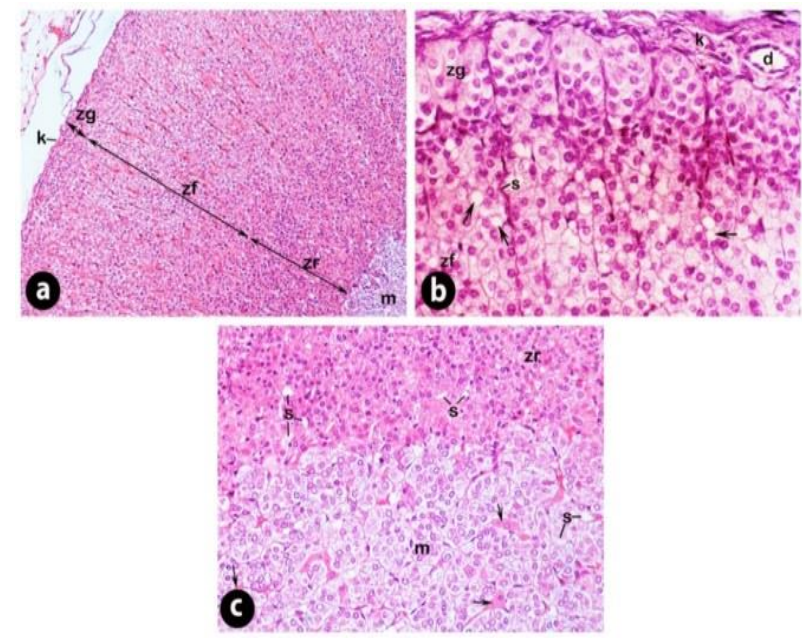

Sekil 3. Diși kontrol grubundaki sıçanlardan elde edilen adrena bezlerin 1şık mikrografi. a) k: kapsül, zg: zona glomeruloza, zf: zona fasikülata, zr: zona retikülaris, m: medulla, Büyütme: X100. b) k: kapsül, d: damar, zg: zona glomeruloza, zf: zona fasikülata, ok: zona fasikülata hücreleri içindeki yağ damlaları, s: sinüzoidler, Büyütme: X400. c) zr: zona retikülaris, m: medulla, s: sinüzoidler, ok: medulla hücreleri arasına sarkmış zona retikülaris hücreleri, Büyütme: X200. Boya: H-E.

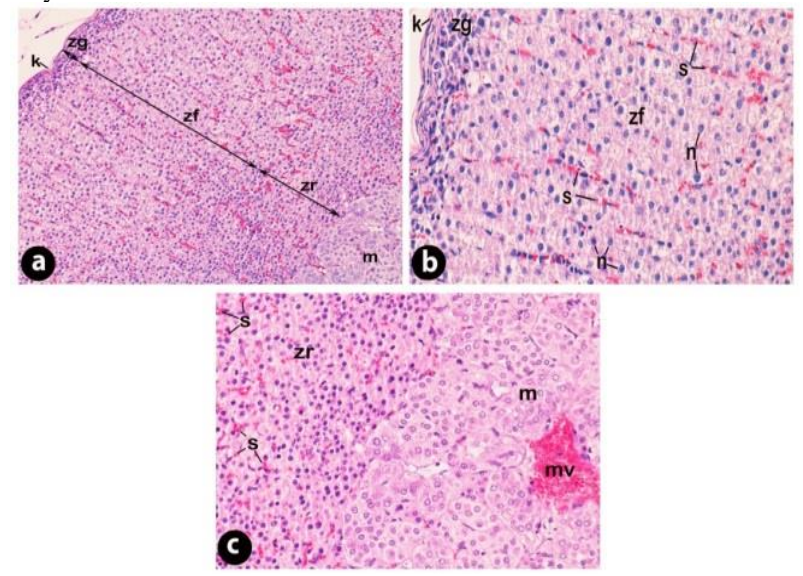

Şekil 4. Erkek kontrol grubundaki sıçanlardan elde edilen adrena bezlerin 1şık mikrografi. a) k: kapsül, zg: zona glomeruloza, zf: zona fasikülata, zr: zona retikülaris, m: medulla, Büyütme: X100. b) k: kapsül, zg: zona glomeruloza, zf: zona fasikülata, s: sinüzoidler, n: nukleus, Büyütme: X200. c) zr: zona retikülaris, m: medulla, s: sinüzoidler, mv: medullar ven, Büyütme: X200, Boya: H-E. 
Dişi stres grubuna ait adrenal bez kesitleri incelendiğinde korteksin, kontrol grubuna kıyasla daha geniş olduğu (Şekil 5a), zona glomeruloza hücrelerinde de sitoplazmik şişme ve nukleusta büzüşme ile karakterize piknozisin geliştiği gözlendi. Zona fasikülata hücrelerinin süngerimsi görünümlerini kaybedip daha koyu eozinofilik boyandığı, sitoplazmalarında eozinofilik granülasyonların olduğu, nukleuslarının da piknotik yapıda olduğu görüldü (Şekil 5b). Ayrıca zona glomeruloza ve zona fasikülata arasında, yer yer mitotik figürlerin olduğu bol hücreli alanlar mevcuttu (Şekil 5c). Zona retikülariste genişlemiş sinüzoidler, piknotik görünümlü küçük ve yoğun kromatinli nukleusu olan hücreler tespit edildi. Bu tabaka hücrelerinin arasında ve sinüzoidlerin çevresinde sar1-kahverengi lipofussin pigmenti içeren makrofajların varlığ 1 da dikkat çekmekteydi. Ayrıca zona retikülariste ve özellikle korteks-medulla sınırında kümeler halinde lenfosit benzeri hücrelerin olduğu alanlar görülmekteydi. Medulla hücrelerinin arasında da piknotik çekirdekli daha asidofilik sitoplazmalı hücreler mevcuttu (Şekil 5d).

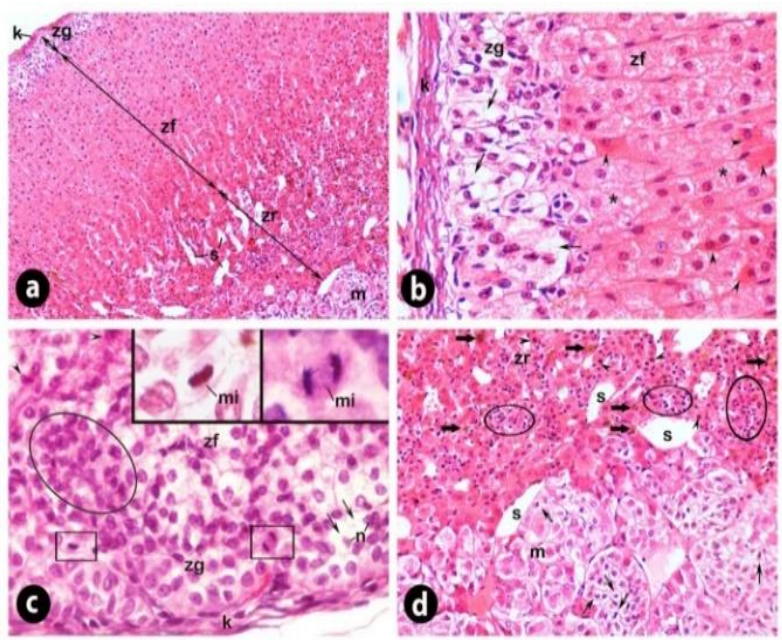

Sekil 5. Diși stres grubundaki sıçanlardan elde edilen adrenal bezlerin ışık mikrografi. a) k: kapsül, zg: zona glomeruloza, zf: zona fasikülata, zr: zona retikülaris, m: medulla, s: genişlemiş sinüzoidler, Büyütme: X100. b) k: kapsül, zg: zona glomeruloza, zf: zona fasikülata, ince ok: sitoplazması şişmiş piknotik nukleuslu zona glomeruloza hücreleri, yıldız: zona fasikülata hücrelerinde eozinofil granülasyon, ok bașı: zona fasikülatada koyu eozinofil sitoplazmalı hücreler, Büyütme: X400. c) k: kapsül, zg: zona glomeruloza, zf: zona fasikülata, mi: mitotik figür (dikdörtgen alan, X600), ince ok: zona glomeruloza hücrelerinde hidropik dejenerasyon, n: büzüşmüş piknotik nukleuslar, çember: zg ve zf arasında çok sayıda küçük hücre içeren saha, Büyütme: X400. d) zr. zona retikülaris, $\mathrm{m}$ : medulla, s: genişlemiş sinüzoidler, kalın ok: makrofaj, ince ok: piknotik nukleuslu medulla hücreleri, ok başı: piknotik çekirdekli eozinofilik sitoplazmalı retikülaris hücreleri, çember: lenfosit benzeri hücrelerin bulunduğu alanlar, Büyütme: X200, Boya: H-E.

Erkek stres grubuna ait adrenal bez kesitlerinde, korteksin kontrol grubuna kıyasla oldukça genişlemiş olduğu, zona fasikülata ve zona retikülaris tabakalarının ise daha kalın olduğu göze çarpmaktaydı. Zona fasikülatanın zona retikülarise yakın olan bölümündeki hücreler kontrole kiyasla daha koyu eozinofilik boyanmıştı (Şekil 6a). Daha büyük büyütme ile incelendiğinde erkek stres grubunda zona glomeruloza hücrelerinde sitoplazmik şişme göze çarpmaktaydı. Zona fasikülata tabakasındaki hücrelerde ise sitoplazmik şişme, koyu eozinofilik boyanma, kromatin yoğunlaşması ve piknozis mevcuttu (Şekil 6b). Dişi stres grubunda olduğu gibi bu grupta da zona glomeruloza ve zona fasikülata hücreleri arasında mitotik figürlere rastladığımız küçük hücreli alanlar göze çarpmaktaydı (Şekil 6b-c). Zona retikülaris tabakasında yer yer küçük ve piknotik nukleus içeren büzülmüş hücreler, yer yer de ökromatik nukleuslu, eozinofilik boyanmış iri hücreler görülmekteydi. Zona retikülaris hücreleri arasında ve sinüzoid kapillerler çevresinde, sar1-kahverengi lipofussin pigmenti içeren makrofajlar dikkat çekiciydi. Medullada ise piknotik görünümlü nukleusa sahip, hücre membranı altındaki sitoplazmik kısmı boş gibi görünen hücreler mevcuttu (Şekil 6d).

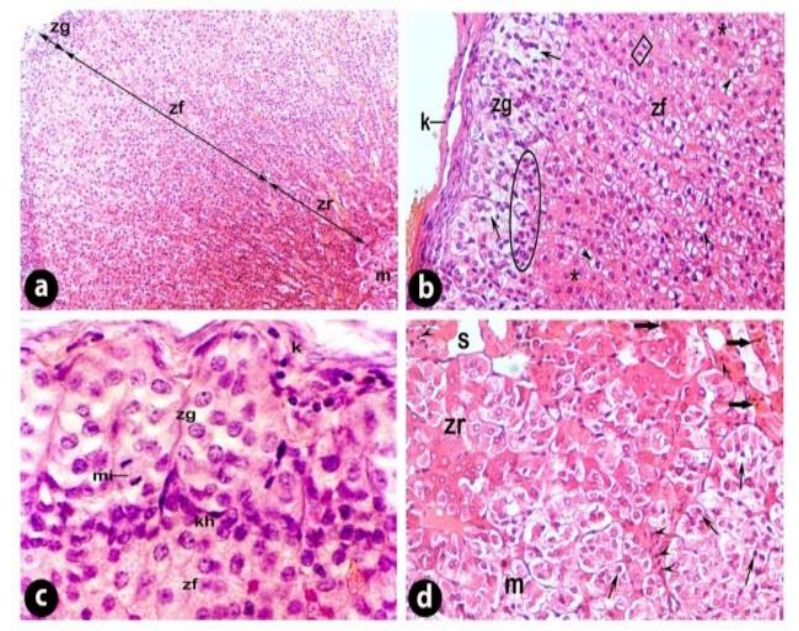

Şekil 6. Erkek stres grubundaki sıçanlardan elde edilen adrenal bezlerin ıș1k mikrografi. a) zg: zona glomeruloza, zf: zona fasikülata, zr: zona retikülaris, m: medulla, Büyütme: X100. b) k: kapsül, zg: zona glomeruloza, zf: zona fasikülata, ince ok: sitoplazması şişmiş zg hücreleri, yıldız: koyu eozinofil sitoplazmalı zf hücreleri, ok başı: sitoplazması şişmiş piknotik nukleuslu zf hücreleri, dikdörtgen: mitotik figür, çember: zg ve zf arasındaki küçük hücreler, Büyütme: X200. c) k: kapsül, zg: zona glomeruloza, zf: zona fasikülata, mi: mitotik figür kh: küçük hücreli bölüm, Büyütme: X600. d) zr: zona retikülaris, m: medulla, s: sinüzoidler, kalın ok: makrofaj, ince ok: medulladaki piknotik nukleuslu hücreler, ok başı: küçük ve koyu nukleuslu zr hücreleri, Büyütme: X200, Boya: H-E.

\subsubsection{Masson trikrom boyama ile elde edilen bulgular}

Diși kontrol ve stres gruplarında, Masson trikrom yöntemi ile boyanmış adrenal bez kesitleri incelendiğinde, bezi kuşatan bağ dokusu kapsülündeki kollagen lifler mavi renkte boyanmış olarak görülmekteydi. Diși kontrol grubuna ait kesitlerde kapsülün altındaki korteks ve medulla tabakaları ise normal histolojik görünümdeydi (Şekil 7a-b). Dişi stres grubunun zona glomeruloza hücrelerindeki sitoplazmik şişme ve zona fasikülata hücrelerinin nukleuslarındaki kromatin yoğunlaşması ve piknotik değişiklikler Masson trikrom tekniği ile de belirgin şekilde gözlenmekteydi. Ayrıca zona fasikülatada hücre sınırlarının düzensizleștiği, hücre yapılarının bozulduğu, zona retikülarisin bazı hücrelerinde sitoplazmik çözülme tarzında vakuolizasyon ve nukleusta küçülmeyle birlikte kromatin yoğunlaşması, bazı hücrelerde ise oldukça koyu 
sitoplazmik boyanma görüldü. Dişi stres grubunun adrenal medullasında piknotik nukleuslu hücrelerin yanı sıra bağ dokusundaki artışta göze çarpmaktaydı (Şekil $7 \mathrm{c}-\mathrm{d})$.

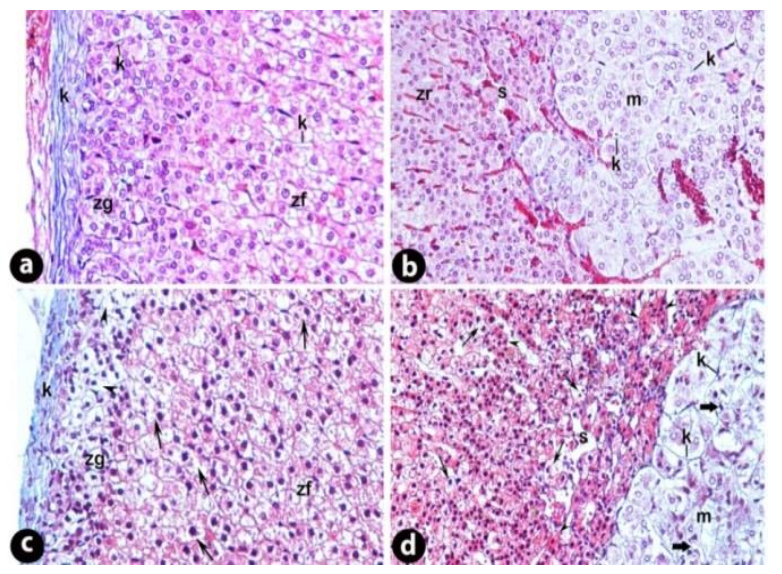

Şekil 7. Diși kontrol (a-b) ve diși stres (c-d) gruplarından alınan adrenal bezlerin 1 şı mikrografları. a) zg: zona glomeruloza, zf: zona fasikülata, k: kollagen lifler. b) zr: zona retikülaris, m: medulla, s: sinüzoidler, k: kollagen lifler. c) zg: zona glomeruloza, zf: zona fasikülata, k: kollagen lifler, ok: bozuk görünümlü zf hücreleri, ok bașı: sitoplazması şișmiş zg hücreleri. d) m: medulla, s: sinüzoidler, k: kollagen lifler, kalın ok: piknotik nukleuslu medulla hücreleri, ince ok: zr hücrelerinde sitoplazmik çözülme, ok başı: koyu retikülaris hücreleri. Büyütme: X200, Boya: Masson trikrom.

Erkek kontrol ve erkek stres gruplarının Masson trikrom ile boyanmış adrenal bez kesitlerinde bezi kuşatan bağ dokusu kapsülünde, mavi renkte boyanmış çok sayıda kollagen lif belirgin olarak görülebiliyordu (Şekil 8a-b). Erkek stres grubunun adrenal medullasinda ve zona retikülarisinde genişlemiş damarlar çevresinde belirgin olarak mavi renkli kollagen lifler ve artmış bağ dokusu içeriği tespit edildi (Şekil 8c-d).

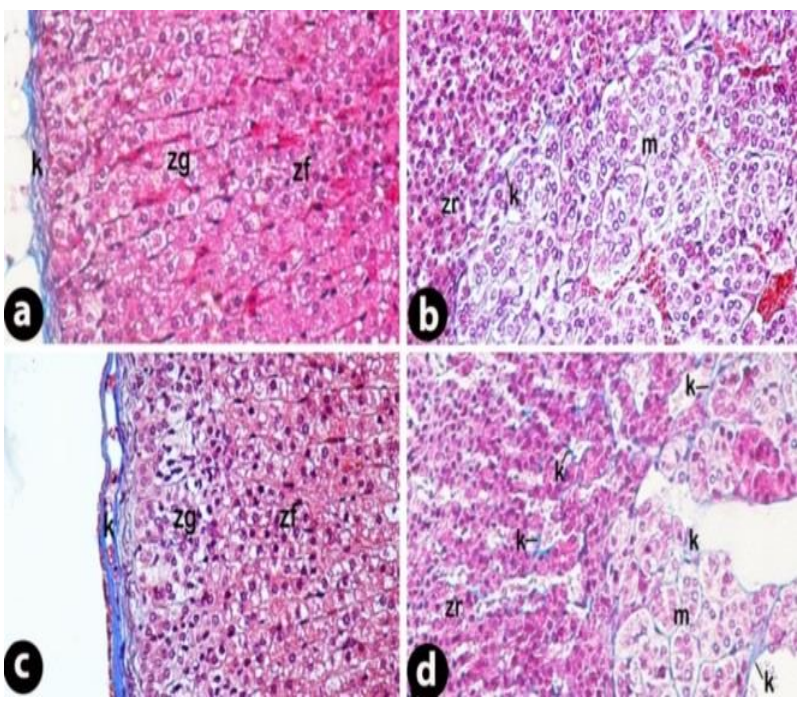

Şekil 8. Erkek kontrol (a-b) ve erkek stres (c-d) gruplarından alınan adrenal bezlerin ışık mikrografları. a) zg: zona glomeruloza, zf: zona fasikülata, k: kollagen lifler. b) zr: zona retikülaris, m: medulla, k: kollagen lifler. c) zg: zona glomeruloza, zf: zona fasikülata, k: kollagen lifler. d) zr: zona retikülaris, m: medulla, k: kollagen lifler. Büyütme: X200, Boya: Masson trikrom.

\subsubsection{PAS boyama ile elde edilen bulgular}

Dişi sıçanlara ait kontrol ve stres grubu adrenallerine PAS reaksiyonu uygulandıktan sonra, güçlü PAS (+) reaksiyon gösteren hücreler görüldü. PAS $(+)$ reaksiyon veren hücrelerin, özellikle zona retikülariste parankimal hücrelerin arasında ve sinüzoidlerin çevresinde belirgin olarak görülebilen düzensiz şekilli koyu pembe-mor sitoplazmalı makrofajlar olduğu tespit edildi. Stres grubuna ait adrenallerin zona retikülarisinde daha bol miktarda makrofaj ve daha geniş lümenli sinüzoid kapillerler görülmekteydi (Şekil 9a-b).

Erkek kontrol ve stres gruplarının PAS ile boyanmış adrenal bezlerinde, diğer boyamalarda görülen benzer oluşumların yanı sıra, özellikle sinüzoidler çevresinde yerleşmiş düzensiz şekilli PAS (+) adrenal makrofajlar görüldü. Erkek stres grubunun adrenal korteksinde, makrofajların özellikle zona fasikülatada artmış olduğu belirlendi (Şekil 9c-d).

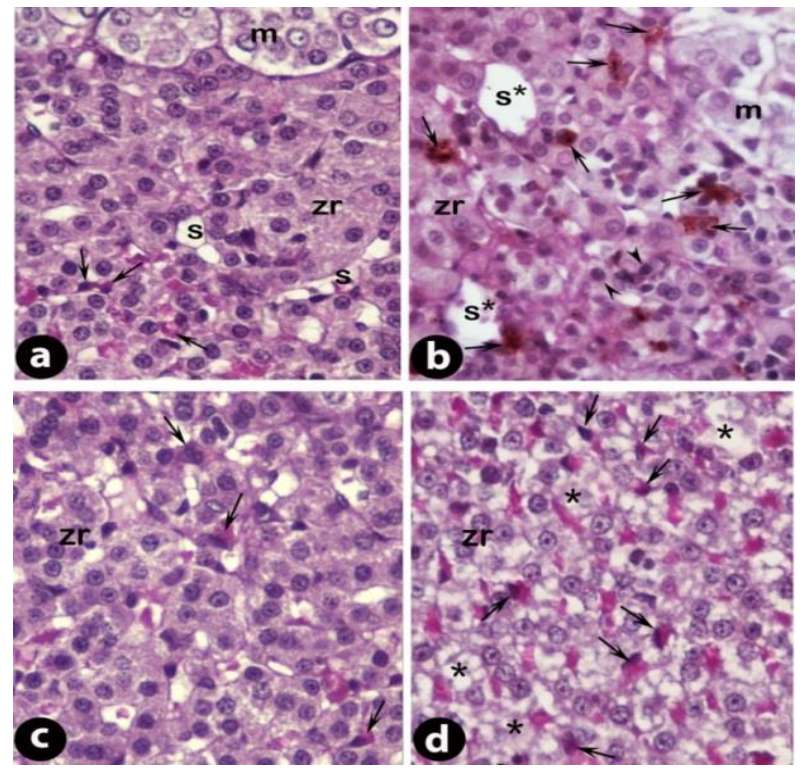

Sekil 9. Dişi kontrol (a), diși stres (b), erkek kontrol (c) ve erkek stres (d) gruplarından alınan adrenal bezlerin ışık mikrografları. a) zr: zona retikülaris, m: medulla, s: sinüzoidler, ok: makrofajlar. b) zr: zona retikülaris, m: medulla, s*: genișlemiș sinüzoidler, ok: makrofajlar, ok başı: piknotik nukleuslu zr hücreleri. c) zr: zona retikülaris, ok: makrofaj. d) zr: zona retikülaris, ok: makrofaj, yıldız: zr hücrelerinde sitoplazmik şişmeler. Büyütme: X400, Boya: PAS reaksiyonu.

\subsection{Tartışma}

Çevresi ile sürekli etkileşim içinde olan canlıların sağlıklı bir şekilde yaşamlarını sürdürebilmeleri, yaşadıkları çevre ile aralarında dengenin kurulması ile sağlanır. Bu dengenin sağlanmasında biyo-psiko-sosyal mekanizmalar rol almaktadır. Organizmanın karşılaştığ 1 birtakım güçlükler, onun çevresiyle kurmaya çalıştığ dengeyi bazen kısa zamanlı bazen de uzun zamanlı olarak bozmaktadır [17, 18].

Strese maruz kalan bir organizmada, bu duruma uyum sağlayabilmek için bir dizi yanıt şekillenir [19]. Meydana gelen bu fizyolojik yanıtlar, canlının stres koşullarından zarar görmemesi ve hayatını sürdürebilmesi açısından oldukça önemlidir [9]. Fizyolojik yanıt, HPA aksının ve sempatik sinir sisteminin aktivasyonu ile başlatılır [10, 
11]. Ad1 geçen bu sistemler, stres boyunca vücut homeostazisinin devamlılığı için çalışırlar. Bu sistemlerin vazgeçilmez birer parçası olan adrenal bezler de stres faktörlerinden en çok etkilenen yapıların başında gelmektedir [12].

Canlının kronik stresle başa çıkabilmesi için stres faktörlerine karşı yanıt oluşturması gereklidir, ancak uzun süren ve tekrarlayan stres faktörleriyle mücadele vücut için tehlike oluşturmaktadır. Çünkü strese yanıt sisteminin aşırı uyarılması sonucunda CRH'ın (Kortikotropin salgılattırıcı hormon) ve buna bağlı olarak ACTH (Adrenokortikotropik hormon) uyarısıyla glukokortikoidlerin salgılanması da yoğun bir şekilde devam eder [20, 21]. Bu yoğun salgilanma ise bir süre sonra tiroid, üreme, metabolizma ve immun sistem fonsiyonlarında bozukluklara ve psikiyatrik hastalıklara neden olabilmektedir [21]. Kronik beklenmedik stres modeli hayvanlarda endojen depresyon oluşturmak için kullanılan bir modeldir [22, 23]. Stres nedeniyle CRH ve ACTH'da meydana gelen artış sonucunda, ACTH'ın kontrolü altında olan adrenal kortekste büyümenin oluşması beklenmektedir. Yaptığımız çalışmada strese maruz bırakılan dişi ve erkek stres gruplarının adrenal korteks kalınlığında önemli ölçüde artışlar tespit ettik. Daha önce yapılan bazı çalışmalarda da kronik stresin adrenal bez ağırlığında artışa yol açabileceği bildirilmiştir [24, 25]. Stres koşullarında artan glukokortikoid salgılanmasından zona fasikülatanın, kısmen de zona retikülarisin sorumlu olduğu düşünülürse stres sonucunda sentez ve salgilama aktiviteleri artan bu tabakaların genişlediği, dolayısıyla adrenal korteksin kalınlaşmasına neden olabilecekleri düşünülebilir. Stres faktörleri karşısında artan ACTH'in adrenokortikal hipertrofiye [20, 26] ve hiperplaziye [27] neden olduğu, bazı araştırmalarda rapor edilmiştir. Kronik strese maruz kalan sıçanların adrenal bezlerinde gözlenen hipertrofiye, bazal plazma kortikosteron seviyelerindeki artışın eşlik ettiğini bildiren çalışmalar da vardır [26]. Yine ACTH salgılamasının DNA, RNA ve protein sentezini artırarak adrenal kortekste genişlemeye [28] böylece adrenokortikal tabaka kalınlıklarında artışa sebep olduğu [27] yapılan çalışmalarda gösterilmiştir. Pignatelli ve arkadaşları [29], hücre döngüsünün sadece $\mathrm{S}$ fazında bulunan hücreleri boyayan bir enzim kullanarak, ACTH etkisiyle gelişen hücre çoğalmasının zona glomeruloza, zona intermedia ve en çokta kapsülde meydana geldiğini göstermişlerdir. Biz, stres uygulanan dişi ve erkek sıçanlarda adrenal korteksin özellikle dış zonlarında, mitozun değişik evrelerinde olan çok sayıda mitotik figür gördük. ACTH'ın zona glomeruloza ve zona fasikülatada hücre çoğalmasını hızlandırdığını oluşan yeni hücrelerin sentripetal şekilde hareket ederek zona retikülariste biriktiğini $[30,31]$ gösteren çalışmalar da mevcuttur. $\mathrm{Bu}$ doğrultuda yapılan başka bir araştırmada bromodeoksiüridin (BrdU) ile işaretlenen hücrelerin başlangıçta en çok zona glomeruloza ile dış zona fasikülatada olduğu ve bu immunopozitif hücrelerin zamanla korteksin derinlerine doğru hareket ettiğ görülmüştür [32].
Kronik streste ACTH uyarısıyla metabolik aktivitesi ve hücre proliferasyonu artan adrenal bezlerde, "fonksiyon morfolojiyi belirler" ilkesinden hareketle, korteks kalınlığında bir değişikliğin oluşması da doğal olarak beklenmektedir. Biz de çalışmamızda erkek stres grubunda, total korteks kalınlığının kontrole kıyasla anlamlı derecede artmış olduğunu, dişi stres grubunda ise, kontrole kıyasla anlamlı olan kortikal büyümenin erkek stres grubundaki korteks büyümesinden istatistiksel olarak daha az olduğunu tespit ettik. Bu çalışmada ayrıca, dişi stres grubundaki sıçanlarda önemli derecede zayıflama (vücut ağırlığında azalma) görülmesine karşın, stres uygulanan erkeklerde ağırlık artışı istatistiksel olarak anlamlı olmasa da devam etmişti. Kanımızca, stres uygulanan dişilerde erkeklere nazaran daha fazla büyüdüğü düşünülen adrenal medulladan katekolamin deşarjı da daha fazla olacağ için, dişilerde daha çok adrenalin salgılanmasıyla gittikçe hızlanacak olan vücut metabolizması, zayıflamanın nedeni olabilir. Nitekim, stresin adrenal medullada hücresel hipertrofiye sebep olduğunu bildiren çalışmalar da vardir [33, 34].

Stres nedeniyle tüm vücutta metabolizma hızlanmakta ve hücrelerde oksidatif stres artmaktadır. Vücutta artan oksidatif stres ise serbest radikalleri artırarak dokularda lipid peroksidasyonuna sebep olmakta [35] bu durum da lipid içeriğinden zengin hücresel membranlarda yıkıma ve dolayısıyla hücresel hasara yol açmaktadır [36]. Biz de yaptığımız çalışmada, stres gruplarından alınan adrenal bezlerin parankim hücrelerinde vakuolizasyon, sitoplazmik şişme, sitoplazmik ve nükleer yoğunlaşma gibi çeşitli yapısal hasarlar tespit ettik. Strese bağlı olarak adrenal kortekste artan steroidogenez sirasinda mitokondri faaliyetleri artmakta ve gelen uyaranlar mitokondri zarının geçirgenliğini artırmaktadır. Geçirgenliğin artması sonucunda mitokondriyal bir protein olan sitokrom c sitosole geçmekte ve bu durum da hücrelerde apoptotik süreci başlatmaktadır [37]. Stres gruplarına ait bezlerin mikroskobik kesitlerinde gördüğümüz koyu asidofil sitoplazmalı ve kromatini yoğunlaşmış olan küçük hücreler apoptotik hücreler olabilir. Daha önce bahsettiğimiz şekilde, stres gruplarının adrenal bezlerinde sıklıkla rastladığımız mitotik figürler ise bezin büyümesine hizmet etmenin yanı sıra, oluşan bu hücre kaybını telafi etmeye de yönelik olabilir.

Salgılanması artan ACTH'ın etkisiyle büyüyen adrenal kortekste metabolik aktivitesi artan hücrelerin yaşlanıp yıpranması sonucunda, metabolik artıkların sitoplazmada birikmesiyle oluşan lipofussin pigment granüllerinin de artması doğaldır [38]. Hücrelerdeki dejenerasyonu takiben artan hücresel debrisi ortadan kaldırmak amacıyla "biyolojik çöpçüler" olarak adlandırılan makrofajların da arttığı bilinmektedir [39, 40]. Biz de 14 günlük stres uygulamamızın sonunda adrenal bezlerde düzensiz şekilli, sar1-kahverengi pigment granülleri içeren, yüksek lizozomal içeriği nedeniyle PAS (+) reaksiyon veren makrofajları bol miktarda gördük. Stres uygulanan sıçanların adrenal bezlerinde, metabolik aktivitelerinin artması nedeniyle yıpranıp hasarlanan 
hücrelerin ve oluşan hücre artıklarının fagosite edilerek ortadan kaldırılması için makrofajların artmış olduğunu düşündük. Makrofajlardan salgılanan sitokinlerin fibroblast proliferasyonunu uyarıcı etkiye sahip olduğu bilinmektedir. Özellikle IL-1 $\alpha$ ve IL-1 $\beta$ sitokinlerinin fibroblast proliferasyonunu, prokollajen tip I ve tip II sentezini artırdığı dolayısıyla fibrozise neden olduğu da bildirilmektedir [41]. Masson trikrom boyama ile kontrol gruplarına kıyasla stres gruplarında daha belirgin olarak gözlediğimiz kollagen liflerdeki artışın sebebi de muhtemelen bu durum olmalidir.

Adrenal bezlerden salgilanan hormonların hepsi steroid bileşikleridir. Steroid hormonlarının sentezlenmesi için gereken kolesterol, kortikal hücrelerde kolesterol esterlerine çevrilerek lipid damlaları şeklinde depolanır. Bu nedenle normal koşullarda kortikal hücreler, özellikle de zona fasikülata çok sayıda lipid damlacığına sahiptir. Ancak stres faktörünün etkisiyle artmış ACTH'ın uyarısıyla, lipid damlacıklarında depo edilen kolesterolden, steroidler sentezlenip salgılanır. Bunun sonucunda da kortikal hücrelerdeki lipid damlalarında azalma meydana gelir [28]. Artmış ACTH salgısıyla bağlantılı olarak erken evrede zona fasikülata hücrelerindeki lipid damlacıklarında azalma olduğundan söz eden çalışmalar vardır [42, 43]. Biz de kontrole kıyasla dişi stres grubunun zona fasikülata hücelerinde lipid damlalarında azalma gördük. Ancak, erkek stres grubunun zona fasikülatasında özellikle dış kısımdaki hücrelerin soluk sitoplazmalı ve kontrole kıyasla daha vakuollü bir görüntüye sahip olduğunu gözlemledik. Yapılan bir çalışmada stres uygulanan sıçanların adrenal kortekslerinde özellikle zona fasikülatada açık ve koyu renk bölgelerin olduğu, açık renk görünen bölgelerdeki hücrelerin büyük lipid damlacıklarıyla dolu iken, bu durumun koyu renk bölgelerde görülmediği bildirilmiştir [44]. Ayrıca, ACTH'ın etkisiyle erken evrede lipid damlacıklarındaki azalma görülmesine karşın, uzun süreli ACTH etkisi altında lipid damlacıklarında tekrar artış gözlendiği bilinmektedir [28]. Hücrelerin bu aşırı vakuollü görünümü, artan hücresel metabolizma sonucunda ortaya çıkan hücresel yıpranmayı ve hasarı da gösteriyor olabilir. Stresin ayrica zona retikülariste büzülmeye [43], zona retikülaris hücrelerinin sitoplazma yoğunluğunda azalmaya [45], nukleus yoğunluğunda ise artı̧̧a neden olduğu da rapor edilmiştir [44].

Depresyon kronik stresle ilişkili bir hastalık olarak tanımlanmakta ve kronik stres uygulanan sıçanlarda görülen endokrin değişikliklerle depresyonlu insanlarda görülen endokrin değişikliklerin aynı olduğu bilinmektedir [46]. Depresyonlu hastaların çoğunda, artan HPA aksı aktivitesiyle ilgili olarak bahsedilen hormonal ve histolojik değişikliklerin tümü görülmektedir [20]. Ayrıca stresin birçok psikolojik hastalığa yol açtığı ve bu hastalıkların da dişilerde görülme prevalansının erkeklere oranla daha fazla olduğu da bilinen bir gerçektir [47, 48]. Aşırı kilo almanın etiyolojisi ile kronik stres arasındaki bağlantı tam olarak anlaşılamamıştır. Ancak Björntorp [49] abdominal obezite ile stres arasındaki bağlantının temelinde, fizyolojik mekanizmaların olduğunu ve stres etkeniyle artan kortizol sekresyonu sonucunda visseral yağ birikiminin arttığını düşünmektedir. Dolayısıyla kronik stres sonucunda artan kortizol sekresyonu, enerji ve yağ alınımının artmasına sebep olmaktadir. Torres ve Nowson'a [50] göre ise obezite durumu, yeme davranışıyla stres arasındaki ilişkiye bağlıdır. Yani; kronik stresin, insanların yeme alışkanlıklarını özellikle aşırı lezzetli ve bol enerjili yiyecekleri tercih edip yeme yönünde etkilediğini düşünmektedirler. Deneyimizde stres uygulanan dişi sıçanlar ile erkek sıçanlar arasında gözlenen farklı bulguların nedeni belki de budur.

\section{Sonuç}

Araştırmadan elde edilen sonuçlar doğrultusunda; kronik stresin hem dişi hem erkek bireylerde adrenal bezlerde hasara neden olduğu, bu hasarın da farklı cinsiyetlerdeki fizyolojik ve metabolik etkilerinin farklı olabildiği gösterilmiştir. Bireylerin yaşamlarını daha sağlıklı sürdürebilmeleri için kronik stres faktörlerinden uzak durmaları önerilmektedir.

\section{Teşekkür ve Bilgilendirme}

Bu makale Semin GEDİKLİ'nin Yüksek Lisans tezinden hazırlanmıştır.

\section{Referanslar}

1. Kocatürk, P.A, Strese cevap, Ankara Üniversitesi Tip Fakültesi Mecmuası, 2000, 53, 01

2. Kaba, İ, Stres, ruh sağlığı ve stres yönetimi: Güncel bir gözden geçirme, Akademik Bakış Uluslararası Hakemli Sosyal Bilimler Dergisi, 2019, 73, 63-81.

3. Aksoy, A, Çalışma hayatında stres kaynakları, stres belirtileri ve stres sonuçlarının incelenmesi üzerine bir araștırma, Sosyal Siyaset Konferanslar Dergisi, 2005, 49.

4. Irwin, M, Daniels, M, Smith, T.L, Bloom, E, Weiner, H, Impaired natural killer cell activity during bereavement, Brain, Behavior, and Immunity 1987, 1(1), 98-104.

5. Bahçıvan, C, Söğüt, İ, Hürdağ, C, Çikler-Dülger, E, Kronik sudan kaçınma stresi ile testis dokusunda olușturulan hasarı üzerine fulvik asidin tedavi edici etkisinin araştırılması, Bozok Tıp Dergisi, 2018, 8(4), 60-68.

6. Balcığlu, İ, Savrun, M, Stres ve hormonlar, Turkiye Klinikler Journal of Psychiatry, 2001, 2(1), 43-50.

7. Santos, J, Benjamin, M, Yang ,P-C, Prior, T, Perdue, M.H, Chronic stress impairs rat growth and jejunal epithelial barrier function: role of mast cells, American Journal of Physiology-Gastrointestinal and Liver Physiology, 2000, 278(6), G847-G854.

8. Eşel, E, Depresyondaki nöroendokrinolojik bulgular, Klinik Psikiyatri Dergisi, 2002, 5(Supp: 4), 35-50.

9. Ulrich-Lai, Y.M, Figueiredo, H.F, Ostrander, M.M, Choi, D.C, Engeland, W.C, Herman, J.P, Chronic stress induces adrenal hyperplasia and hypertrophy in a subregion-specific manner, American Journal of Physiology-Endocrinology and metabolism, 2006, 291(5), E965-E973.

10. Smith, S.M, Vale, W.W, The role of the hypothalamic-pituitaryadrenal axis in neuroendocrine responses to stress, Dialogues in Clinical Neuroscience, 2006, 8(4), 383.

11. Jacobson, L, Sapolsky, R, The role of the hippocampus in feedback regulation of the hypothalamic-pituitary-adrenocortical axis, Endocrine Reviews, 1991, 12(2), 118-134.

12. Willenberg, H, Bornstein, S, Dumser, T, Ehrhart-Bornstein, M, Barocka, A, Chrousos, G, Scherbaum, W, Morphological changes in adrenals from victims of suicide in relation to altered apoptosis, Endocrine Research, 1998, 24(3-4), 963-967.

13. Dalla, C, Antoniou, K, Drossopoulou, G, Xagoraris, M, Kokras, N, Sfikakis, A, Papadopoulou-Daifoti, Z, Chronic mild stress impact: are females more vulnerable? Neuroscience, 2005, 135(3), 703-714.

14. Endo, Y, Shiraki, K, Behavior and body temperature in rats following chronic foot shock or psychological stress exposure, Physiology \& Behavior, 2000, 71(3-4), 263-268 
15. Konkle, A.T, Baker, S.L, Kentner, A.C, Barbagallo, L.S-M, Merali, Z, Bielajew, C, Evaluation of the effects of chronic mild stressors on hedonic and physiological responses: sex and strain compared, Brain Research, 2003, 992(2), 227-238.

16. Altunkaynak, B.Z, Özbek, E, Overweight and structural alterations of the liver in female rats fed a high-fat diet: a stereological and histological study, Turkish Journal of Gastroenterology, 2009, 20(2), 93-103.

17. Savrun, M, Balcıoğlu, İ, Tan, O, Nöropsikoendokrinoloji, Yeni Symposium, 1997, 35(2-3), 78-86.

18. Yıldırım, N.C, Yürekli, M, Yıldırım, N, Soğuk stresi, adrenomedullin ve metile adrenomedullin uygulamalarının bazı sıçan dokularında toplam RNA miktarları üzerine etkileri, Dicle University Journal of Ziya Gokalp Education Faculty, 2009, 13.

19. Yasemin, Ö, Karabulut, A.B, Günlük yaşam ve stres yönetimi, Türkiye Să̆lık Bilimleri ve Arastırmaları Dergisi, 2018, 1(1), 48-56.

20. Dumser, T, Barocka, A, Schubert, E, Weight of adrenal glands may be increased in persons who commit suicide, The American Journal of Forensic Medicine and Pathology, 1998, 19(1), 72-76.

21. De Vriendt, T, Moreno, L.A, De Henauw, S, Chronic stress and obesity in adolescents: scientific evidence and methodological issues for epidemiological research, Nutrition, Metabolism and Cardiovascular Diseases, 2009, 19(7), 511-519.

22. Bekris, S, Antoniou, K, Daskas, S, Papadopoulou-Daifoti, Z, Behavioural and neurochemical effects induced by chronic mild stress applied to two different rat strains, Behavioural Brain Research, 2005, 161(1), 45-59

23. Lucca, G, Comim, C.M, Valvassori, S.S, Pereira, J.G, Stertz, L Gavioli, E.C, Kapczinski, F, Quevedo, J, Chronic mild stress paradigm reduces sweet food intake in rats without affecting brain derived neurotrophic factor protein levels, Current Neurovascular Research, 2008, 5(4), 207-213.

24. Rygula, R, Abumaria, N, Flügge, G, Fuchs, E, Rüther, E, HavemannReinecke, U, Anhedonia and motivational deficits in rats: impact of chronic social stress, Behavioural Brain Research, 2005, 162(1) $127-134$

25. Sterlemann, V, Ganea, K, Liebl ,C, Harbich, D, Alam, S, Holsboer, F, Müller, M.B, Schmidt, M.V, Long-term behavioral and neuroendocrine alterations following chronic social stress in mice: implications for stress-related disorders, Hormones and Behavior 2008, 53(2), 386-394

26. Zelena, D, Mergl, Z, Foldes, A, Kovacs, K, Toth, Z, Makara, G, Role of hypothalamic inputs in maintaining pituitary-adrenal responsiveness in repeated restraint, American Journal of Physiology-Endocrinology and Metabolism, 2003, 285(5), E1110 E1117.

27. Miśkowiak, B, Kasprzak, A, Malendowicz, L, Comparative stereological studies on the effects of long term CRF and ACTH treatment on the cortex of the suprarenal gland, Journal of Anatomy, $1986,146,167$

28. Özbek, E, Akçay, G, Kobay adrenal korteksinin erken ve gec gebelik dönemlerinde kıyaslı yapısı: morfometrik ve 1 şı mikroskopik çalışma, Atatürk Üniversitesi Diş Hekimliği Fakültesi Dergisi, 2000, 2, 34-41.

29. Pignatelli, D, Ferreira, J, Vendeira, P, Magalhaes, M, Vinson, G Proliferation of capsular stem cells induced by ACTH in the rat adrenal cortex, Endocrine Research, 2002, 28(4), 683-691.

30. Belloni, A, Mazzocchi, G, Meneghelli, V, Nussdorfer, G, Cytogenesis in the rat adrenal cortex: evidence for an ACTH-induced centripetal cell migration from the zona glomerulosa, Archives D'anatomie D'histologie et D'embryologie Normales et Experimentales, 1978, 61, 195-205.

31. Stachowiak, A, Nussdorfer, G, Malendowicz, L, Proliferation and distribution of adrenocortical cells in the gland of ACTH-or dexamethasone-treated rats, Histology and Histopathology, 1990 $5(1), 25-9$

32. McNicol, A, Duffy, A, A study of cell migration in the adrenal cortex of the rat using bromodeoxyuridine, Cell Proliferation, 1987, 20(5), $519-526$.

33. Gosney, J, Adrenal corticomedullary hyperplasia in hypobaric hypoxia, The Journal of Pathology, 1985, 146(1), 59-64

34. Wolman, M, Cervos-Navarro, J, Sampaolo, S, Cardesa, A Pathological changes in organs of rats chronically exposed to hypoxia. Development of pulmonary lipidosis, Histology and Histopathology, 1993, 8(2), 247-55.

35. Mercan, U, Toksikolojide serbest radikallerin önemi, Yüzüncü Yll Üniversitesi Veteriner Fakültesi Dergisi, 2004, 15(1), 91-96.

36. Özbek, E, Özbek, A, Microscopic pathology of the liver in rats fed a Fusarium graminearum-inoculated diet, Journal of International Medical Research, 2003, 31(5), 392-401.

37. Öztürk, F, Apopitoz, İnönü Üniversitesi Tıp Fakültesi Dergisi, 2002 $9(2), 143-148$

38. Özbek, E, Kobay adrenal korteksinde gestasyonel değișiklikler: morfometrik ve histolojik bir çalışma, Türkiye Klinikleri Journal of Case Reports, 1999, 17(3), 133-139.

39. Stroikin, Y, Mild, H, Johansson, U, Roberg, K, Öllinger, K, Lysosome-targeted stress reveals increased stability of lipofuscincontaining lysosomes, Age, 2008, 30(1), 31-42.

40. Grune, T, Merker, K, Jung, T, Sitte, N, Davies, K.J, Protein oxidation and degradation during postmitotic senescence, Free Radical Biology and Medicine, 2005, 39(9), 1208-1215.

41. Yaylac1, M, Öztürk, A, Türken, O, Üskent, N, Granülosit-Makrofaj Koloni Stimülan Faktör (GM-CSF) = Diğer Sitokinlerle Etkilessimi Ve Klinik Kullanım Alanları, Türkiye Klinikleri Tıp Bilimleri Dergisi, 1994, 14(5), 373-377.

42. Koldysheva, E, Lushnikova, E, Ultrastructural reorganization of rat adrenal cortex after whole body hyperthermia, Bulletin of Experimental Biology and Medicine, 2008, 145(5), 650-655.

43. Koldysheva, E, Lushnikova, E, Nepomnyashchikh, L, Tornuev, Y.V, Morphogenesis of adaptation and compensatory reactions in mouse adrenals during restitution after thermal exposure, Bulletin of Experimental Biology and Medicine, 2005, 140(4), 464-467.

44. Koko, V, Djordjeviæ, J, Cvijiæ, G, Davidoviæ, V, Effect of acute hea stress on rat adrenal glands: a morphological and stereological study, Journal of Experimental Biology, 2004, 207(24), 4225-4230.

45. Pellegrini, A, Soldani, P, Gesi, M, Lenzi, P, Natale, G, Paparelli, A, Effect of varying noise stress duration on rat adrenal gland: an ultrastructural study, Tissue and Cell, 1997, 29(5), 597-602.

46. Katz, R.J, Roth, K.A, Carroll, B.J, Acute and chronic stress effects on open field activity in the rat: implications for a model of depression, Neuroscience \& Biobehavioral Reviews, 1981, 5, 247-251.

47. Herzog, C, Czéh, B, Corbach, S, Wuttke, W, Schulte-Herbrüggen, O, Hellweg, R, Flügge, G, Fuchs, E, Chronic social instability stress in female rats: a potential animal model for female depression, Neuroscience, 2009, 159(3), 982-992.

48. Westenbroek, C, Den Boer, J.A, Veenhuis, M, Ter Horst, G.J, Chronic stress and social housing differentially affect neurogenesis in male and female rats, Brain Research Bulletin, 2004, 64(4), 303-308.

49. Björntorp, P, Do stress reactions cause abdominal obesity and comorbidities? Obesity Reviews, 2001, 2(2), 73-86

50. Torres, S.J, Nowson, C.A, Relationship between stress, eating behavior, and obesity, Nutrition, 2007, 23(11-12), 887-894.

http://edergi.cbu.edu.tr/ojs/index.php/cbusbed isimli yazarın CBU-SBED başlıklı eseri bu Creative Commons Alıntı-Gayriticari4.0 Uluslararası Lisansı ile lisanslanmıştır.

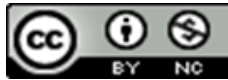

